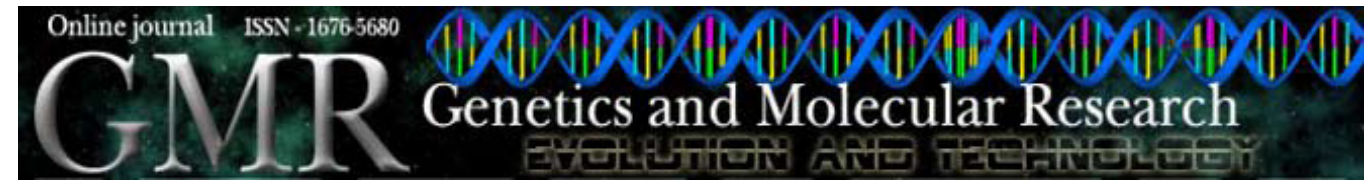

\title{
Can established cultured papilloma cells harbor bovine papillomavirus?
}

\author{
S.R.C. Campos ${ }^{1}$, C. Trindade ${ }^{1}$, O.P. Ferraz ${ }^{1}$, D.N.S. Giovanni ${ }^{1}$, \\ A.A. Lima ${ }^{1,2}$, H.V.A. Caetano ${ }^{1,3}$, R.F. Carvalho ${ }^{1,3}$, E.H. Birgel Jr. ${ }^{4}$, \\ M.L.Z. Dagli ${ }^{3}$, E. Mori ${ }^{5}$, P.E. Brandão ${ }^{5}$, L.J. Richtzenhain ${ }^{5}$, W. Beçak ${ }^{1,6}$ \\ and R.C. Stocco ${ }^{1}$ \\ ${ }^{1}$ Laboratório de Genética, Instituto Butantan, São Paulo, SP, Brasil \\ ${ }^{2}$ Escola de Farmácia, Universidade Federal de Ouro Preto, \\ Ouro Preto, MG, Brasil \\ ${ }^{3}$ Departamento de Patologia, Faculdade de Medicina Veterinária e Zootecnia, \\ Universidade de São Paulo, São Paulo, SP, Brasil \\ ${ }^{4}$ Departamento de Clínica Médica, \\ Faculdade de Medicina Veterinária e Zootecnia, \\ Universidade de São Paulo, São Paulo, SP, Brasil \\ ${ }^{5}$ Departamento de Medicina Veterinária Preventiva e Saúde Animal, \\ Faculdade de Medicina Veterinária e Zootecnia, \\ Universidade de São Paulo, São Paulo, SP, Brasil \\ ${ }^{6}$ Departamento de Genética, Universidade Federal de Pernambuco, \\ Recife, PE, Brasil
}

Corresponding author: R.C. Stocco

E-mail: ritastocco@butantan.gov.br

Genet. Mol. Res. 7 (4): 1119-1126 (2008)

Received July 22, 2008

Accepted August 5, 2008

Published October 21, 2008

ABSTRACT. Papillomaviruses have been reported to be very dif-
ficult to grow in cell culture. Also, there are no descriptions of cell
cultures from lesions of bovine cutaneous papillomatosis, with
identification of different bovine papilloma virus (BPV) DNA se-
quences. In the present report, we describe primary cell cultures 
from samples of cutaneous lesions (warts). We investigated the simultaneous presence of different BPV DNA sequences, comparing the original lesion to different passages of the cell cultures and to peripheral blood. BPV 1, 2 and 4 DNA sequences were found in lesion samples, and respective cell cultures and peripheral blood, supporting our previous hypothesis of the possible activity of these sequences in different samples and now also showing how they can be maintained in different passages of cell cultures.

Key words: Papillomavirus; Bovine papilloma virus; Primary cell cultures; Wart; Cutaneous papillomatosis

\section{INTRODUCTION}

Bovine papillomavirus (BPV)-associated diseases are important in veterinary medicine and can also be considered as possible important models for the study of human papillomavirus (HPV) (Borzacchiello and Roperto, 2008). In cattle, papillomas, BPVrelated benign lesions, detected in different organs, generally regress. Natural regression of papillomas can occur and the histological examination of the lesions reveals an intense infiltration of lymphocytes in the dermis and epithelium (Campo, 2003; Jelínek and Tachezy, 2005). Occasionally these lesions can persist and develop into cancer, mostly when associated with environmental co-factors: chronic exposure to immunosuppressants leads to the persistence and spreading of the papillomas. Often, immunosuppression in cattle results from exposure to bracken fern: some animals become unable to reject the infection and succumb to widespread cutaneous or mucosal involvement (Borzacchiello and Roperto, 2008). These stages of papillomatosis are problematic leading to economic losses (Yaguiu et al., 2006, 2008).

Six types of BPV have been described (1-6), and recently, four other types were reported. BPV-1 causes teat and penile fibropapillomas; BPV-2 is associated with cutaneous warts, alimentary fibropapillomas and urinary bladder tumors; BPV-3 causes cutaneous papillomas; BPV-4 is associated with pure epithelial papillomas of the upper gastrointestinal tract; BPV-5 induces fibropapillomas of the udder; BPV-6 causes papillomas of the teats; BPV-8 causes cutaneous papillomas; BPV-9/10 are associated with epithelial squamous papillomas of the udder (Borzachiello and Roperto, 2008).

Recently, the simultaneous presence of more than two viral agents infecting a single individual in the same tissue has been described (Yaguiu et al., 2006, 2008). The co-existence of different pathogens in the same tissue can result in deleterious interactions with the host cells and with the host chromatin (Yaguiu et al., 2008).

BPV is described as epithelium-specific (Campo, 2003). However, the presence of viral DNA sequences in different cells such as those of peripheral blood and gametes has been reported (Stocco dos Santos et al., 1998; Carvalho et al., 2003; Freitas et al., 2003). The significance of the presence of these nucleic acid sequences in these tissues has not yet been determined, considering that there is yet no evidence of expression of these nucleic acid sequences and of their potential to initiate infection.

Possible evidence of effects of these nucleic acid sequences can include chromo- 
somal abnormalities found in peripheral blood lymphocytes from chronically infected animals (Walter-Moura et al., 1988) or animals experimentally exposed to the virus (Stocco dos Santos et al., 1998) or in a cell line obtained from bovine palate fibroblasts submitted to a specific protocol of transfection with active Ha-ras, BPV-4 protein E7 and exposed to quercetin pulse (Leal et al., 2003). These detected chromosome aberrations can indicate a possible action of viral DNA sequences on the host chromatin and its eventual expression (Avanzo JL, Góes LGB, Dagli MLZ, Birgel EH Jr., et al., unpublished results).

The biological implications of the presence of virus DNA sequences of different types in different organs are important aspects of our studies.

In this study, we compared the presence of BPV DNA sequences in blood and papillomas of cattle with papillomatosis. Samples of the papillomas were used to establish primary cell cultures, and the detection of BPV sequences was performed in different passages and compared with the data obtained from the initial papilloma sample and from blood.

\section{MATERIAL AND METHODS}

\section{Animal selection}

We selected 4 Bos taurus taurus animals: 3 Holstein cows, aged 3, 6 and 8 years, respectively, and 1 male half-breed Jersey, aged 14 months.

\section{Collection of samples}

Blood and tissue samples were collected for analysis. A sample of $10 \mathrm{~mL}$ of blood was collected for each analysis using disposable syringes and needles and stored in tubes containing anticoagulant (EDTA). Wart samples were obtained by incision parallel to the surface of the skin using a disposable sterile scalpel, and kept at $4{ }^{\circ} \mathrm{C}$ until the specific procedures.

\section{DNA extraction}

All samples collected were submitted to total DNA extraction using a commercially available kit, DNeasy Blood and Tissue kit (Qiagen), according to manufacturer instructions.

\section{BPV detection}

For the detection of BPV, $300 \mathrm{ng}$ DNA, isolated from the samples, were amplified by PCR using primers specific for BPV1 (Fw 5'-ggagcgcetgctaactatagga-3' and $\mathrm{RV}$ 5'-atctgttgtttgggtggtgac-3'), BPV2 (Fw 5'-gttataccacccaaagaagaccct-3' and $\mathrm{Rv}$ 5'-ctggttgcaacagctctctttctc-3') and BPV4 (Fw 5'-gctgaccttccagtcttaat-3' and Rv 5'-cagtttcaatctcctcttca-3'). These primers are complementary to the L2 and L1 regions of the BPV genomes, for BPV1 and BPV2, respectively, and to the E7 region of BPV4, amplifying fragments of 301, 164 and $170 \mathrm{bp}$, respectively. The PCR protocol was 
according to Yaguiu et al. (2008) using appropriate controls. As a control of the quality of DNA for PCR, the bovine $\beta$-globin gene was amplified using specific primers (Fw: 5'AAC CTC TTT GTT CAC AAC CAG - 3' and Rv: 5' - CAG ATG CTT AAC CCA CTG AGC - 3') that yielded a 430-bp fragment, according to a protocol described by Yaguiu et al. (2008).

\section{Sequencing}

We selected BPV1 PCR products for sequencing to serve as positive controls of the BPV determination from wart samples of animals 2 and 3, using the dideoxynucleotide chain termination method with the BigDye ${ }^{\mathrm{TM}}$ Terminator kit (Applied Biosystems ${ }^{\mathrm{TM}}$ ), and sequences were determined with an automatic sequencer (ABI model 377, Applied Biosystems ${ }^{\mathrm{TM}}$ ) according to manufacturer instructions. DNA samples were amplified using one PCR primer pair: FAP59 (forward; 59-TAACWGTIGGICAYCCWTATT-39) and FAP64 (reverse; 59-CCWATATCWVHCATITCICCATC-39), following the protocol: denaturation at $94^{\circ} \mathrm{C}$ for $10 \mathrm{~min}, 45$ cycles for $1.5 \mathrm{~min}$ at $94^{\circ} \mathrm{C}, 1.5 \mathrm{~min}$ at $50^{\circ} \mathrm{C}$ and $1.5 \mathrm{~min}$ at $72^{\circ} \mathrm{C}$, and a final extension at $72^{\circ} \mathrm{C}$ for $5 \mathrm{~min}$. The DNA sequences were compared with all sequences in the GenBank through the BLAST server (National Center for Biotechnology Information; http://www.ncbi. nlm.nih.gov/blast/).

\section{Histology}

Wart samples were prepared on histological slides of tissue sections $(1.5 \mathrm{~mm})$ that were stained with hematoxylin and eosin by routine procedures.

\section{Generation and establishment of cultured wart cells}

Tissue samples were carefully dissected and washed with PBS containing $300 \mu \mathrm{L} /$ $\mathrm{mL}$ penicillin, $300 \mu \mathrm{L} / \mathrm{mL}$ streptomycin and $2.5 \mu \mathrm{L} / \mathrm{mL}$ amphotericin B for $5 \mathrm{~min}$. Collagenase, $10 \mathrm{mg} / \mathrm{mL}$, was added $(100 \mu \mathrm{L})$, and the samples were kept for $40 \mathrm{~min}$ at $37^{\circ} \mathrm{C}$. The cells were incubated in warm Dulbecco's modified Eagle's medium (DMEM) supplemented with $10 \%$ fetal bovine serum, $100 \mu \mathrm{L} / \mathrm{mL}$ penicillin, $100 \mu \mathrm{L} / \mathrm{mL}$ streptomycin and $0.25 \mu \mathrm{L} /$ $\mathrm{mL}$ amphotericin B, seeded in T25 flasks in $10 \mathrm{~mL}$ of the same complete DMEM and incubated in a $37^{\circ} \mathrm{C}$ humidified atmosphere of $5 \% \mathrm{CO}_{2}$ in air until cells reached confluence and then, submitted to trypsinization. All cells were maintained in culture in the same complete DMEM in a $37^{\circ} \mathrm{C}$ humidified atmosphere of $5 \% \mathrm{CO}_{2}$ in air.

\section{RESULTS}

The animals involved in this study were selected from different herds to avoid possible cross-contamination.

Figure 1 shows the histological analyses, confirming the normal structure of the sample obtained from control skin samples, the specific characteristics of papillomas and the morphology of cultured wart cells.

The BPV-1 PCR products from wart samples from animals 2 and 3 were obtained us- 

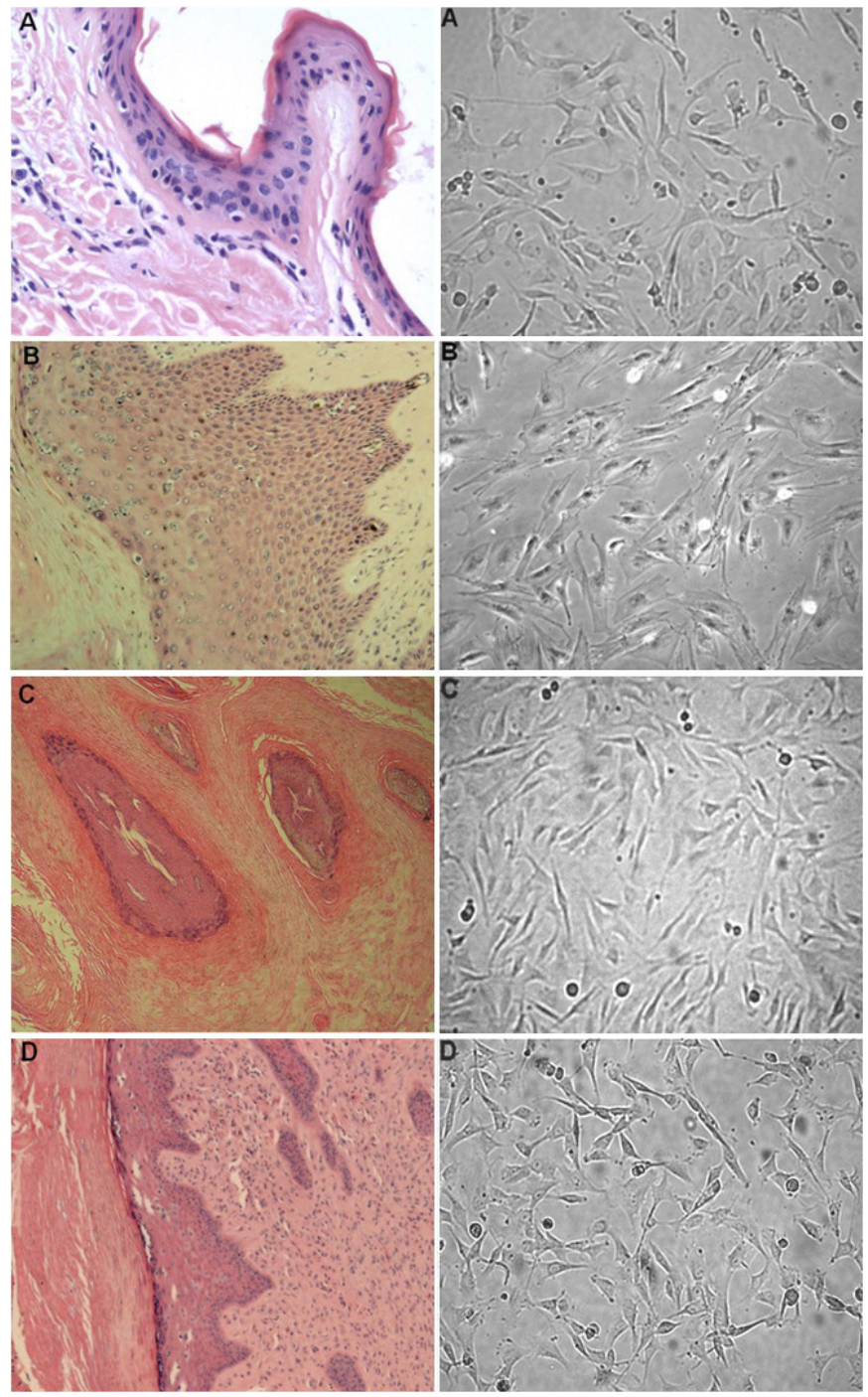

Figure 1. Histological appearances of papillomas (40X) and morphology of respective cultured cells (100X). A. Normal skin and its cultured cells from animal 1. B. C. D. Segments of papilloma lesions and cultured cells from animals 2, 3 and 4, respectively.

ing generic primers (FAP59 and FAP64). They were sequenced and used as positive control for the PCR products and the L1 region of BPV-1, 98\% (Table 1).

PCR analysis showed different types of BPV sequences to be present in wart and blood samples collected, as well as in the cell cultures established from the wart fragments (data summarized in Table 1). 


\begin{tabular}{|c|c|c|c|c|c|c|c|c|}
\hline \multirow[t]{2}{*}{ Animal } & \multirow[t]{2}{*}{ Age } & \multirow[t]{2}{*}{ Gender } & \multirow[t]{2}{*}{ Clinical aspects } & \multirow[t]{2}{*}{ Breed } & \multicolumn{3}{|c|}{ Virus type detected in specific sample } & \multirow{2}{*}{$\begin{array}{c}\text { Number of } \\
\text { passages submitted } \\
\text { to virus detection }\end{array}$} \\
\hline & & & & & Wart & Blood & Culture & \\
\hline 1 (control) & $6-8$ years & $\mathrm{F}$ & Normal & Holstein & - & - & - & 4 \\
\hline 2 & 11 months & M & Cutaneous papillomatosis & $1 / 2$ Jersey & $1^{*}(98 \%), 2,4$ & $1,2,4$ & $1,2,4$ & 10 \\
\hline 3 & 6 years & $\mathrm{F}$ & $\begin{array}{l}\text { Cutaneous papillomatosis, } \\
\text { Esophageal carcinoma, } \\
\text { Bladder carcinoma }\end{array}$ & Holstein & $1^{*}(98 \%), 2,4$ & 4 & - & 4 \\
\hline 4 & 3 years & $\mathrm{F}$ & Cutaneous papillomatosis & Holstein & 1,2 & - & 2 & 5 \\
\hline
\end{tabular}

The PCR products showed the presence of DNA sequences of the three types of BPV investigated (1,2 and 4) in animal 2: wart, blood, and in all passages of the primary culture (Figure 2A). In animal 3, the wart sample showed type 1, 2 and 4 virus DNA sequences, but only type 4 could be detected in blood and none of them were found in culture, in any of the 4 passages analyzed. In animal 4, no virus DNA could be detected in blood, but the DNA detected in the culture and subcultures was of the same type detected in the wart sample (type 2). In animal 4, it was possible to detect also type 1 DNA in the wart sample (Figure 2B and C).

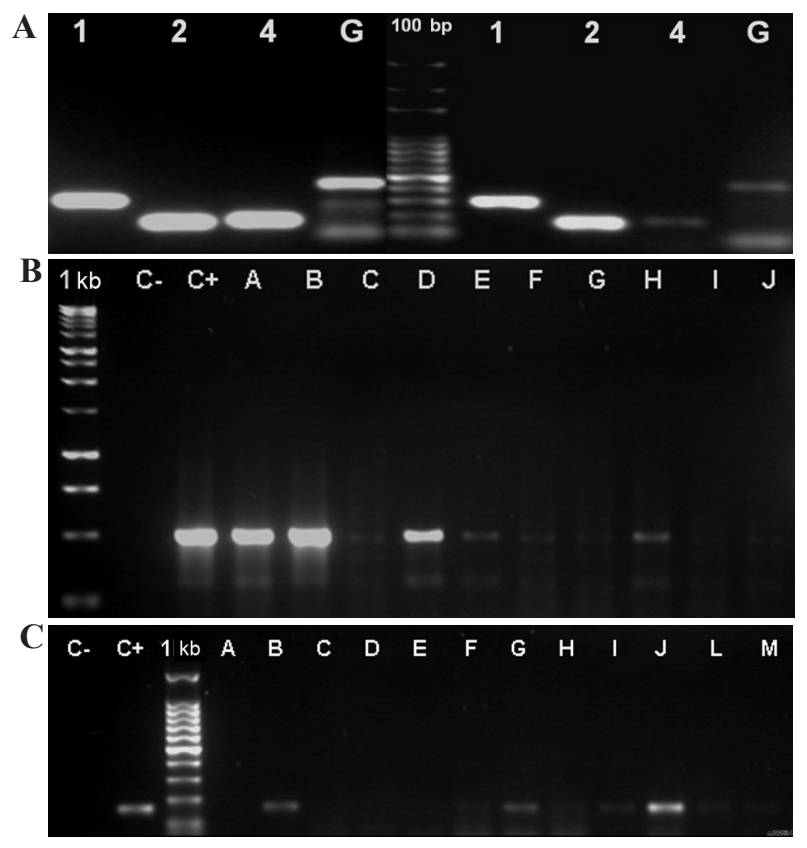

Figure 2. PCR amplification of BPV DNA in bovine papilloma lesions, in respective cultured cells (in different passages) and blood. A. Animal 2: $\mathrm{A}_{1}$-positive controls: $\mathrm{BPV}_{1}$ (lane 1), $\mathrm{BPV}_{2}$ (lane 2), $\mathrm{BPV}_{4}$ (lane 4), $\beta$-globin (lane G). $\mathrm{A}_{2}$ BPV DNA sequences detected in cultured cells: $\mathrm{BPV}_{1}$ (lane 1), $\mathrm{BPV}_{2}$ (lane 2), $\mathrm{BPV}_{4}($ lane 4$)$, $\beta$-globin (lane G). B. BPV DNA sequences detected with primers FAP59/64 in papilloma wart collected from animal 4 (A and $B)$ and in sequential passages obtained from primary cell line: passage $1(\mathrm{C}-\mathrm{E})$, passage $2(\mathrm{~F}-\mathrm{H})$ and passage $3(\mathrm{I}, \mathrm{J})$. C. BPV2 DNA sequences detected in wart collected from animal 4 (A and B) and in sequential passages of respective primary cell lines: passage $1(\mathrm{C}-\mathrm{E})$, passage $2(\mathrm{~F}-\mathrm{H})$, passage $3(\mathrm{I}, \mathrm{J})$, passage $4(\mathrm{~L})$ and passage $5(\mathrm{M})$. 


\section{DISCUSSION}

It has been discussed that BPV can remain in a latent stage (Campo et al., 1994): viral genomes have been detected in bovine normal epithelia and in clinically normal hosts (Borzacchiello and Roperto, 2008). BPV DNA can occur in circulating lymphocytes of cattle, and latent BPV infection of lymphocytes was induced in experimental cattle (Stocco dos Santos et al., 1998). We have previously described the presence of BPV DNA in different tissues, not only epithelia, with evidence of virus activity (Yaguiu et al., 2006, 2008).

The BPV genome is found in the host cells in the episomal form and is segregated in cell division linked to the host chromatin (McBride et al., 2006). This interaction with the host chromatin can also be related to the chromosome aberrations that are described in infected lymphocytes (Yaguiu et al., 2008).

Considering that the viral genome can be present in different tissues, in latent or active conditions, these viral DNA sequences have to be investigated in the lesions and in other tissues such as blood.

Moreover, if the virus sequences are linked to the host chromatin, they should be segregated in a similar way not only in lesion cells, but also in other tissue cells and in cultivated cells from the BPV-related lesions.

In the present study, we obtained primary cultures from bovine wart fragments. The biopsies were collected from affected animals with severe cutaneous papillomatosis, and/or upper alimentary tract and bladder cancer. We compared the virus sequences in the original lesion with those detected in the blood. These sequences were also found in different passages of the cell cultures.

The results presented demonstrate some interesting data: not all virus DNA found in wart samples could be detected in all the samples or cultures of all animals. It is possible that the PCR procedures were not sensitive enough to detect very low virus load.

Considering the virus-host chromatin interaction, the levels of cells with chromosome aberrations have been analyzed in cells obtained from short-term lymphocyte cultures and from primary wart cell cultures, and the results indicate virus presence (Campos SRC, Trindade C, Ferraz OP, Giovanni DNS, et al., unpublished results). It is remarkable to identify in these cells, rearrangements quite similar to those described by Leal et al. (2003), in cultured fibroblasts transformed by virus oncoprotein and exposed to quercetin.

The primary cell cultures were not analyzed concerning the prevalent cell type: keratinocyte or fibroblast. Yet, the maintenance of virus DNA through the passages leads to interesting questions concerning in vitro production of virus.

\section{ACKNOWLEDGMENTS}

The authors thank Carolina da Paz Sabino for her editorial support, MCT/CNPq, DECIT/ MS, Fundo Setorial de Biotecnologia (CT-Biotecnologia) e Saúde (CT-Saúde) and FAPESP for the fellowships (project Nos. 507376/2004-8, 554816/2006-7 and 2006/02439-6, respectively).

\section{REFERENCES}

Borzacchiello G and Roperto F (2008). Bovine papillomaviruses, papillomas and cancer in cattle. Vet. Res. 39: 45. Campo MS (2003). Papillomavirus and disease in humans and animal. Vet. Comp. Oncol. 1: 3-14. 
Campo MS, Jarrett WF, O’Neil W and Barron RJ (1994). Latent papillomavirus infection in cattle. Res. Vet. Sci. 56: 151-157.

Carvalho C, Freitas AC, Brunner O, Góes LGB, et al. (2003). Bovine papillomavirus type 2 in reproductive tract and gametes of slaughtered bovine females. Braz. J. Microbiol. 34 (Suppl. 1): 82-84.

Freitas AC, Carvalho C, Brunner O, Birgel EH Jr, et al. (2003). Viral DNA sequences in peripheral blood and vertical transmission of the virus: a discussion about BPV-1. Braz. J. Microbiol. 34: 76-78.

Jelínek F and Tachezy R (2005). Cutaneous papillomatosis in cattle. J. Comp. Pathol. 132: 70-81.

Leal AM, Ferraz OP, Carvalho C, Freitas AC, et al. (2003). Quercetin induces structural chromosome aberrations and uncommon rearrangements in bovine cells transformed by the E7 protein of bovine papillomavirus type-4. Vet. Comp. Oncol. 1: 15-21.

McBride AA, Oliveira JG and McPhillips MG (2006). Partitioning viral genomes in mitosis: same idea, different targets. Cell Cycle 5: 1499-1502.

Stocco dos Santos RC, Lindsey CJ, Ferraz OP, Pinto JR, et al. (1998). Bovine papillomavirus transmission and chromosomal aberrations: an experimental model. J. Gen. Virol. 79 (Pt 9): 2127-2135.

Walter-Moura J, Stocco dos Santos RC, Dagli MZ, D'Angelino JL, et al. (1988). Chromosome aberrations in cattle raised on bracken fern pasture. Experientia 44: 785-788.

Yaguiu A, Carvalho C, Freitas AC, Góes LGB, et al. (2006). Papillomatosis in cattle: in situ detection of bovine papillomavirus DNA sequences in reproductive tissues. Braz. J. Morphol. Sci. 23: 129-136.

Yaguiu A, Dagli ML, Birgel EH Jr, Alves Reis BC, et al. (2008). Simultaneous presence of bovine papillomavirus and bovine leukemia virus in different bovine tissues: in situ hybridization and cytogenetic analysis. Genet. Mol. Res. 7 : 487-497. 